\title{
CaMKII binding to GluN2B is important for massed spatial learning in the Morris water maze [version 1; peer review: 3
}

\section{approved]}

\author{
Ivar S. Stein, Michaela S. Donaldson, Johannes W. Hell \\ Department of Pharmacology, School of Medicine, University of California, Davis, CA, 95616-8636, USA
}

V1 First published: 12 Aug 2014, 3:193

https://doi.org/10.12688/f1000research.4660.1

Latest published: 12 Aug 2014, 3:193

https://doi.org/10.12688/f1000research.4660.1

\section{Abstract}

Learning and memory as well as long-term potentiation (LTP) depend on $\mathrm{Ca}^{2+}$ influx through the NMDA-type glutamate receptor (NMDAR) and the resulting activation of the $\mathrm{Ca}^{2+}$ and calmodulin-dependent protein kinase (CaMKII). $\mathrm{Ca}^{2+}$ influx via the NMDAR triggers CaMKII binding to the NMDAR for enhanced CaMKII accumulation at postsynaptic sites that experience heightened activity as occurring during LTP. Previously, we generated knock-in (KI) mice in which we replaced two residues in the NMDAR GluN2B subunit to impair CaMKII binding to GluN2B. Various forms of LTP at the Schaffer collateral synapses in CA1 are reduced by $50 \%$. Nevertheless, working memory in the winshift 8 arm maze and learning of the Morris water maze (MWM) task was normal in the KI mice although recall of the task was impaired in these mice during the period of early memory consolidation. We now show that massed training in the MWM task within a single day resulted in impaired learning. However, learning and recall of the Barnes maze task and contextual fear conditioning over one or multiple days were surprisingly unaffected. The differences observed in the MWM compared to the Barnes maze and contextual fear conditioning suggest a differential involvement of CaMKII and the specific interaction with GluN2B, probably depending on varying degrees of stress, cognitive demand or even potentially different plasticity mechanisms associated with the diverse tasks.

\section{Open Peer Review Approval Status \\ 12 \\ 23 \\ version 1 \\ 12 Aug 2014
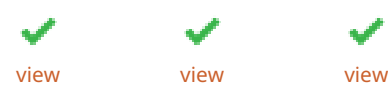 \\ 1. Mark L. Dell'Acqua (iD), University of \\ Colorado Denver, Denver, USA \\ 2. Karl-UIrich Bayer, University of Colorado \\ Denver, Aurora, USA \\ 3. Isabel Pérez-Otaño, Centro de Investigacion en Medicina Aplicada, Pamplona, Spain}

Any reports and responses or comments on the article can be found at the end of the article. 
Corresponding author: Johannes W. Hell (jwhell@ucdavis.edu)

Competing interests: No competing interests were disclosed.

Grant information: This work was supported by NIH grants NS046450 and NS078792 to JWH.

The funders had no role in study design, data collection and analysis, decision to publish, or preparation of the manuscript.

Copyright: @ 2014 Stein IS et al. This is an open access article distributed under the terms of the Creative Commons Attribution License, which permits unrestricted use, distribution, and reproduction in any medium, provided the original work is properly cited. Data associated with the article are available under the terms of the Creative Commons Zero "No rights reserved" data waiver (CCO 1.0 Public domain dedication).

How to cite this article: Stein IS, Donaldson MS and Hell JW. CaMKII binding to GluN2B is important for massed spatial learning in the Morris water maze [version 1; peer review: 3 approved] F1000Research 2014, 3:193 https://doi.org/10.12688/f1000research.4660.1

First published: 12 Aug 2014, 3:193 https://doi.org/10.12688/f1000research.4660.1 


\section{Introduction}

The acquisition and storage of new tasks as well as the modification of already existing memories depend on the selective strengthening and weakening of synaptic interactions embedded in extensive networks of neurons (Kessels \& Malinow, 2009; Martin et al., 2000; Morris, 2013; Neves et al., 2008). Synaptic plasticity and especially long-term potentiation (LTP), a stable increase in synaptic strength, are emerging as the cellular equivalent of learning and memory (Gruart et al., 2006; Whitlock et al., 2006). Two key players involved in LTP are the $\mathrm{Ca}^{2+} /$ calmodulin-dependent protein kinase II (CaMKII) and the NMDA-type glutamate receptor (NMDAR). $\mathrm{Ca}^{2+}$ influx through the NMDAR leads to CaMKII activation and recruitment to the postsynaptic density (PSD), which can be persistent and synapse specific (Otmakhov et al., 2004; Zhang et al., 2008) (but see also (Rose et al., 2009)). CaMKII binding to aa 1290-1309 on the NMDAR GluN2B subunit is required for this activity-dependent translocation (Halt et al., 2012; Leonard et al., 1999; Strack \& Colbran, 1998; Strack et al., 2000) and is crucial for LTP (Barria \& Malinow, 2005; Halt et al., 2012; Zhou et al., 2007). Stimulation of CaMKII results in its auto-phosphorylation on T286 causing a persistent $\mathrm{Ca}^{2+}$-independent activation of CaMKII (Lisman et al., 2002). This auto-phosphorylation is increased after LTP and spatial learning in the Morris water maze (MWM) (Lengyel et al., 2004; Ouyang et al., 1997; Ouyang et al., 1999; Tan \& Liang, 1996) and is required for effective binding of CaMKII to GluN2B (Bayer et al., 2001; Strack \& Colbran, 1998). T286A CaMKII mutant mice exhibit no hippocampal NMDAR dependent LTP and have impaired MWM learning (Giese et al., 1998).

We recently reported the specific disruption of CaMKII binding to GluN2B by point mutations in the GluN2B gene (Halt et al., 2012). The GluN2BKI mice contain two point mutations in the GluN2B C terminus (L1298A and R1300Q). Each of these mutations abolishes CaMKII binding to this site nearly completely in vitro (Strack et al., 2000). In vivo the two point mutations entirely abrogate the activity-dependent increase in the interaction with the NMDAR, show reduced hippocampal LTP by $50 \%$ and result in a MWM memory deficit, while acquisition of the MWM task and working memory as evaluated in the 8 arm win shift test remain normal (Halt et al., 2012).

Now we report a specific moderate spatial learning deficit in the GluN2B knock in (KI) mice during massed 1-day training in the MWM. At the same time learning and memory recall in the Barnes maze and contextual fear conditioning are unaffected.

\section{Material and methods}

Mice

All animal procedures were approved (Protocol \#: 15512; PHS/NIH Assurance A3433-01) by the UC Davis Institutional Animal Care and Use Committee (IACUC) and followed NIH guidelines. All experiments were conducted with litter matched wild type (WT) and GluN2B KI mice of mixed sex (evenly distributed gender ratios) and between 2 and 4 months of age; mice within a cohort were not more than 3 weeks apart. For a more detailed characterization and description of the GluN2B KI mice (C57BL/6J background) including genotyping procedures refer to (Halt et al., 2012). The mice were on a $12 \mathrm{~h} \mathrm{light/dark} \mathrm{cycle,} \mathrm{housed} \mathrm{individually} \mathrm{for} \mathrm{the} \mathrm{behav-}$ ioral experiments and acclimated for at least one week before all procedures. After the acclimation period and before the training and testing the mice were extensively handled (7-10 times for 1-2 min on different days). All trainings and testing were performed during the $12 \mathrm{~h}$ light cycle.

\section{Morris water maze}

The MWM was a circular, enamel coated steel tank, $94 \mathrm{~cm}$ in diameter filled with water at $22-24^{\circ} \mathrm{C}$. For the visible trial, a black labeled square platform $(6 \times 6 \mathrm{~cm})$ emerging $2 \mathrm{~cm}$ out of the opaque (through addition of non-toxic paint) water surface was used, while the clear Plexiglas square platform $(6 \times 6 \mathrm{~cm})$ for the training trials was submerged $2 \mathrm{~cm}$ below the opaque water surface. On the first day, the mice were trained in one visible trial followed by 12 consecutive training trials, while the platform was kept in a fixed position. The mice were always placed facing the wall of the pool and started randomly from three different starting positions that are equally distributed around the perimeter and are not located within the target quadrant. The mice were allowed to swim freely for $90 \mathrm{~s}$ to find the platform. If they failed to locate the platform within time, they were gently guided to it. After the mice climbed on the platform they were allowed to remain $30 \mathrm{~s}$ on the platform before they were removed from the pool and placed in their home cage for an inter-trial interval of 6-10 min. The mice were returned to the pool for a $90 \mathrm{~s}$ probe test without the platform 1 day and 7 days after the training day. The training session and probe trials were monitored and analyzed using the SMART (Version 2.5.19) real-time videotracking system.

\section{Barnes maze}

The Barnes maze was executed according to (Berta et al., 2007). In short, the maze consisted of a circular platform $(92 \mathrm{~cm}$ diameter; opaque white) with 20 equally spaced holes $(5 \mathrm{~cm}$ diameter; $7.5 \mathrm{~cm}$ between holes) and was elevated $105 \mathrm{~cm}$ above the floor. All holes were $2 \mathrm{~cm}$ away from the perimeter of the platform and a dark escape box $(10 \mathrm{~cm} \times 12.5 \mathrm{~cm} \times 12.5 \mathrm{~cm})$ was located beneath one of the holes.

The mouse was placed in a cylindrical black start chamber $(10 \mathrm{~cm} \times$ $12.5 \mathrm{~cm} \times 12.5 \mathrm{~cm}$ ) in the middle of the maze. After $10 \mathrm{~s}$ the chamber was lifted and the mouse was exposed to bright light (500 W). For the habituation trial on day 1 the animal was gently guided to the escape box and once it entered, the entry hole was covered and the mouse kept for $2 \mathrm{~min}$ in the dark escape box. Between each mouse, before the next trial, the platform was cleaned with a $10 \%$ Nolvasan solution to avoid remaining olfactory cues. During the acquisition phase, after the start chamber was lifted, the mouse was allowed to explore the maze for $3 \mathrm{~min}$. The trial ended when the mouse entered the escape box or after $3 \mathrm{~min}$ had elapsed. Immediately after the mouse entered the escape box, the entry hole was covered and the animal stayed for $1 \mathrm{~min}$ in the dark escape box. If the mouse did not reach the target hole/escape box within $3 \mathrm{~min}$, it was gently guided to it. After $1 \mathrm{~min}$ in the escape box, the mouse was placed back in its home cage until the next trial. Each mouse received 4 training trials per day with an inter-trial interval of 10-15 min on 4 consecutive days.

The probe trial was conducted on day 5 , i.e., $24 \mathrm{~h}$ after the last training day, and on day 12. During the probe test the escape box was removed and the mouse was allowed to explore the maze for a fixed 
time of $90 \mathrm{~s}$. The number of pokes (errors) in each hole and the latency and path length to reach the virtual target hole was measured using the SMART (Version 2.5.19) real-time video-tracking system.

\section{Elevated plus maze}

The elevated plus maze (EPM) was a four arm maze with each arm measuring $30 \times 5 \mathrm{~cm}$ and the central platform measured $5 \times 5 \mathrm{~cm}$ (opaque white). One set of arms, opposing one another, were enclosed completely by grey side walls, $15 \mathrm{~cm}$ high, while the other set was open with a ledge of $0.5 \mathrm{~cm}$ on either side of the arms. The maze was elevated $100 \mathrm{~cm}$ from the floor and illuminated evenly with a $500 \mathrm{~W}$ light. Mice were placed on the central platform, facing towards a closed arm, and allowed to freely explore the maze for $5 \mathrm{~min}$. The SMART (Version 2.5.19) real-time tracking software was used to record the locomotor activity and the time spent on both the closed and the open arms during the test.

\section{Fear conditioning}

Contextual fear conditioning was conducted using the 'Video Tracking of Fear Conditioning System' and the 'Video Freeze Software' from MED Associates Inc. The experimentally naïve mice were placed in the conditioning chamber and received the first foot shock at the end of a 3 min habituation period. The mice remained for an additional minute in the chamber after the last foot shock was delivered. For the 5 shock conditioning protocol, the mice received an electric foot shock $(0.75 \mathrm{~mA}, 1 \mathrm{~s})$ at the end of the $3^{\text {rd }}, 4^{\text {th }}, 5^{\text {th }}, 6^{\text {th }}$, and $7^{\text {th }}$ minute. During the milder 3 shock $(0.5 \mathrm{~mA}, 1 \mathrm{~s})$ paradigm, the shock was received at the end of the $3^{\text {rd }}, 4^{\text {th }}$ and $5^{\text {th }}$ minute. For the 4 day training protocol only one shock $(0.75 \mathrm{~mA}, 1 \mathrm{~s})$ per day was delivered after $2.5 \mathrm{~min}$. In case of the milder 3 shock paradigm and the 4 day training protocol the mice were pre-exposed to the conditioning chamber for $3 \mathrm{~min}$ and $10 \mathrm{~min}$ respectively. For recall the mice were placed back for $5 \mathrm{~min}$ in the same chamber after the indicated periods of time. If the mice were exposed to a different context, the chamber geometry was changed (from square to curved wall), the lights were dimmed, the rod-flooring was covered with white linoleum, and the scent was changed from $0.01 \%$ bleach to bubble gum. Using the Video Freeze Program, the freezing time was determined (in \%) and was defined as the absence of any movement, except for respiratory motion. The observed freezing response to the foot shock is correlated to the degree of learning, the strength of the aversive stimulus, and the number of presentations (Curzon et al., 2009).

\section{Statistical analysis}

All data are represented as mean \pm the standard error of the mean (SEM). The data were analyzed by unpaired two-tailed t-test, oneway ANOVA or two-way ANOVA followed by the Bonferroni correction as indicated in the results, using GraphPad Prism 5 software. Statistical significance was considered if $\mathrm{p} \leq 0.05$.

\section{Results}

\section{Single day spatial learning in the MWM is impaired in} GluN2B KI

In order to further dissect the memory deficit observed during the initial MWM experiments (Halt et al., 2012), two independent cohorts of GluN2B KI mice and their WT littermate controls (10 mice of each genotype per cohort) underwent a massed training protocol on a single day in the MWM. Such a compressed training protocol challenges the learning capacity within a short time period. It also has the potential to reveal deficits in early- versus late-phase consolidation as training is not protracted over 6 days as is the case for the classic MWM. The 1 day protocol thus might expose deficits in early consolidation when testing different cohorts 1 and 7 days after the training day without the complication that in the 6 days training paradigm training and consolidation processes overlap. After habituation on the first day (training day), mice underwent one visible platform trial followed by 12 consecutive training trials, in which the platform was no longer visible but kept in a fixed position. The initial trial with a marked visible platform is hippocampus-independent and was conducted to rule out changes in motivation, coordination, or sensory processing in GluN2B KI mice. The latency in reaching the visible platform was not different between the two genotypes (Figure 1A; WT: $51.48 \pm 7.43 \mathrm{~s}, \mathrm{KI}: 46.46 \pm 6.70 \mathrm{~s}$ ). In the following 12 consecutive trials with a submerged platform the KI mice slowly started to show deficits in spatial learning around trial 6 , roughly the onset of learning in the WT mice (Figure 1B). The latencies of the 12 training trials are paired into blocks of two for analysis and the GluN2B KI mice display significantly increased average escape latencies during the last two trials (genotype: $\mathrm{F} 1,228=2.63, \mathrm{p}=0.1061$; trial: $\mathrm{F} 5,228=13.30, \mathrm{p}<0.0001$; genotype $\times$ trial $F 5,228=3.08, p=0.0103$; Bonferroni post hoc test shows that the latency is significantly increased in the $\mathrm{KI}$ mice during the last two trials, $\mathrm{M}_{\text {diff }}=20.30 \mathrm{~s}, 95 \% \mathrm{Cl}[2.58,38.01], \mathrm{p}<0.05$; Figure 1B; $\left.\mathrm{WT}_{11-12}: 30.31 \pm 3.77 \mathrm{~s}, \mathrm{KI}_{11-12}: 50.61 \pm 4.49 \mathrm{~s}\right)$.

The covered distance shows like the escape latency a significant genotype $x$ trial interaction (Figure 1C; genotype: F1,228=0.16, $\mathrm{p}=0.687$; trial: $\mathrm{F} 5,228=43.34, \mathrm{p}<0.0001$; genotype $\times$ trial $\mathrm{F} 5,228=3.13$, $\mathrm{p}=0.0095$ ), strengthening the mild learning deficit observed during the last training trials. No difference was observed between the mean velocity of the WT and GluN2B KI mice (Figure 1D).

During the probe test one day after training, WT mice required significantly less time to reach the original location of the platform as reflected by faster primary escape latency (Figure 1E; WT: 38.09 $\pm 6.15 \mathrm{~s}$, KI: $55.32 \pm 6.91 \mathrm{~s} ; \mathrm{t}(38)=2.15, \mathrm{p}<0.05)$. Analysis of the entries into the quadrants and the area of the former platform location also showed a significant difference between the two genotypes in their preference for the target quadrant (Figure 1F). The KI mice showed compared to WT no real preference for the target quadrant $\mathrm{D}$ and entered it significantly less often (Figure $1 \mathrm{~F}$; $\mathrm{WT}_{\mathrm{D}}$ : $9.45 \pm 0.98, \mathrm{KI}_{\mathrm{D}}: 6.70 \pm 1.22$; genotype: $\mathrm{F} 1,190=3.89, \mathrm{p} \leq 0.05$; quadrant/platform: $\mathrm{F} 4,190=18.99, \mathrm{p}<0.0001$; genotype $\times$ quadrant/ platform $\mathrm{F} 4,190=1.46, \mathrm{p}=0.2147$; Bonferroni post hoc test shows that the WT mice search preferentially in the target quadrant compared to the KI mice, $M_{\text {diff }}=-2.750$ entries, 95\% $\mathrm{Cl}$ [-5.347, -0.153], $\mathrm{p}<0.05)$. The covered distance and mean velocity was not different between the two genotypes (Figure $1 \mathrm{G}$ ), indicating similar activity levels.

During the probe test 7 days after training some of the mice (independent of their genotype) were continuously floating and did not search actively for the escape platform. For the analysis of the 7 day probe trial, these floaters were neglected. The performance in the 

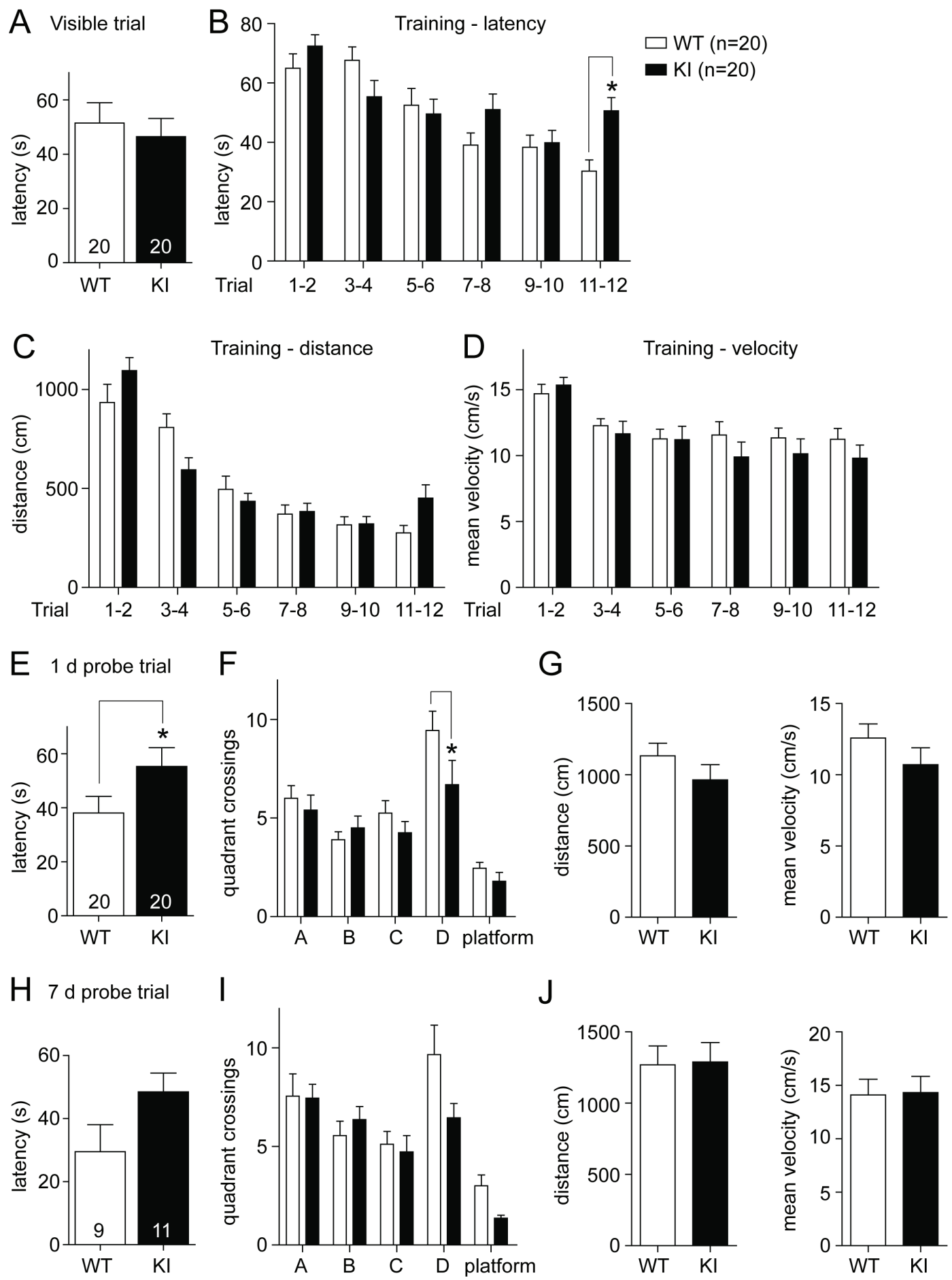

Figure 1. Spatial learning in the Morris water maze (MWM) is impaired in GluN2B KI mice. (A) WT and KI mice display no difference in the average escape latency during the visible platform trial. (B) The GluN2B KI mice show a deficit during acquisition of the hidden platform task. The latencies of the 12 training trials are split up into blocks of two and the average escape latency is significantly increased for KI versus WT mice during the last two training trials. (C, D) The covered distance over the blocks of two training trials is also different between $\mathrm{KI}$ and WT mice $(\mathbf{C})$, while the mean velocity is not changed $(\mathbf{D})$. (E, F) During the probe test 1 day after training the KI mice exhibit increased primary average escape latency $(\mathbf{E})$ and show significantly fewer crossings into the target quadrant $D(\mathbf{F})$, the former location of the submerged platform, compared to WT mice. (G) Both genotypes cover the same distance during the probe trial and display the same mean velocity. (H, I) The KI mice show a similar tendency during the probe test 7 days after training, with extended primary average escape latency $(\mathbf{H})$ and diminished crossings into target quadrant $\mathrm{D}(\mathbf{I})$. (J) The covered distance and mean velocity is again unchanged. (A: adjacent right quadrant to D; B: quadrant opposite to quadrant D; C: adjacent left quadrant to D; platform: area of the former location of the platform). The same two independent cohorts, each consisting of 10 WT and 10 GluN2B KI mice, were tested in the Barnes maze before the MWM. Data represent Mean \pm SEM. 
probe test 7 days after training showed a similar tendency compared to the one day test. The GluN2B KI leaned towards a longer primary escape latency (Figure $1 \mathrm{H}$, left; WT: $29.50 \pm 8.59$ s, KI: $48.50 \pm 5.98 \mathrm{~s} ; \mathrm{t}(18)=1.87, \mathrm{p}=0.078)$ and tended to cross less often over into the target quadrant in search for the platform than WT mice (Figure 1I; $\mathrm{WT}_{\mathrm{D}}: 9.67 \pm 1.49, \mathrm{KI}_{\mathrm{D}}: 6.46 \pm 0.73$; genotype: $\mathrm{F} 1,90=3.12, \mathrm{p}=0.0805$; quadrant/platform: $\mathrm{F} 4,90=16.69, \mathrm{p}<0.0001$; genotype $\times$ quadrant/platform $\mathrm{F} 4,90=1.85, \mathrm{p}=0.1259)$. Both genotypes again showed no observable difference in the covered distance and mean velocity (Figure 1J).

Individual analysis (one-way-ANOVA) of the search pattern (quadrant crossings) reveals that the WT mice preferentially search in the target quadrant during the 1 day $(\mathrm{F} 3,76=11.61, \mathrm{p}<0.0001)$ as well as the 7 day probe trial $(\mathrm{F} 3,32=3.91, \mathrm{p}=0.0175)$. The GluN2B KI mice conversely only show a slight non-significant preference for the target quadrant during the 1 day probe trial and no preference at all during the 7 day probe trial.

\section{Spatial learning and memory is not affected in the Barnes maze}

The Barnes maze is a less aversive spatial learning paradigm, which unlike the MWM allows the mice to move freely and explore the environment under conditions that are less stressful. It is solely based on the motivation of the mice to avoid prolonged exposure to an open area under light and to search for a dark and safe hideout, the escape box. Interestingly, the GluN2B KI showed no detectable deficits not only in learning but also in early memory (Figure 2). These findings contrast what had been seen before after spaced MWM learning experiments conducted over a period of 6 days (Halt et al., 2012). Over the 16 training trials, which were executed on 4 consecutive days (4 trials per day) the latency to locate and enter the escape box decreased equally fast for both genotypes and saturated on the fourth day (Figure 2A; WT: $22.99 \pm 4.08$ s, KI: $20.95 \pm 3.95$ s). During the probe test 1 day after the last training session there was no difference in the primary escape latency (Figure 2B, left; WT: $20.11 \pm 6.02 \mathrm{~s}$, GluN2BKI: $18.68 \pm 4.72 \mathrm{~s}$ ), covered distance (Figure 2B, middle; WT: $355.70 \pm 37.25 \mathrm{~cm}$, GluN2BKI: $426.60 \pm 43.64 \mathrm{~cm})$ or mean velocity (Figure 2B, right; WT: $3.95 \pm 0.41 \mathrm{~cm} / \mathrm{s}$, GluN2BKI: 4.74 $\pm 0.48 \mathrm{~cm} / \mathrm{s}$ ). Both WT and KI mice searched preferentially in the target area and the surrounding holes (areas +1 and -1 ), indicating that they clearly remembered the former location of the escape box (Figure 2B, lower part). The overall number of zone entries and time in zones for GluN2B KI mice showed a slight increase compared to WT mice, which is probably a reflection of the statistically non-significant increased activity of KI as seen in the covered distance and mean velocity (Figure 2B). The performance in the probe test 7 days after the last training session mirrored the results of the 1 day probe test. There was no significant difference in the primary escape latency (Figure 2C, left; WT: $33.37 \pm 7.98 \mathrm{~s}$, KI: $26.80 \pm 6.61 \mathrm{~s}$ ), covered distance (Figure 2C, middle; WT: $265.40 \pm 26.47 \mathrm{~cm}$, GluN2BKI: $353.00 \pm 49.42 \mathrm{~cm})$ and mean velocity (Figure 2C, right; WT: $2.95 \pm 0.29 \mathrm{~cm} / \mathrm{s}$, GluN2BKI: 3.92 $\pm 0.55 \mathrm{~cm} / \mathrm{s}$ ). The slightly increased activity of the GluN2B KI mice is again reflected by an increased number of zone entries and by the time spent in the zones (Figure 2C, bottom).
Basal anxiety levels in the GluN2B KI mice are normal Basal anxiety levels in the GluN2B KI mice were assessed using the EPM. The EPM relies on the rodents' innate fear of heights and open spaces and their preference for dark and enclosed rooms. Basal anxiety levels in the GluN2B KI mice were not different compared to their WT litter-matched controls. During exposure to the EPM the GluN2B KI mice spent most of the time in the closed arms, like the WT controls, and rarely stayed in the open arms or center (Figure 3A; in \% of total time, WT: $92.30 \pm 1.16 \%$, KI: $88.68 \pm 3.27 \%)$. Both genotypes covered comparable minimal distances in the open arms (Figure 3B; WT: $20.63 \pm 3.96 \mathrm{~cm}$, GluN2B KI: $31.62 \pm 10.73 \mathrm{~cm}$ ), while the WT mice had the tendency to be more active in the closed arms. This tendency is displayed in an increase in covered distance (Figure 3B; WT: $881.59 \pm 86.40 \mathrm{~cm}$, $\mathrm{KI}: 626.92 \pm 59.24 \mathrm{~cm}$; genotype: $\mathrm{F} 1,68=10.17, \mathrm{p}=0.0022$; location: $\mathrm{F} 3,68=120.21, \mathrm{p}<0.0001$; genotype $\times$ location $\mathrm{F} 3,68=3.40$, $\mathrm{p}=0.0225$; Bonferroni post hoc test shows that the distance is significantly reduced in the $\mathrm{KI}$ in the closed arms, $\mathrm{M}_{\text {diff }}=-254.7 \mathrm{~cm}$, 95\% $\mathrm{Cl}[-459.5,-49.49], \mathrm{p}<0.01)$ and a trend towards a higher mean velocity in the closed arms (Figure 3C; WT: $3.19 \pm 0.31 \mathrm{~cm} / \mathrm{s}$, GluN2B KI: $2.37 \pm 0.21 \mathrm{~cm} / \mathrm{s}$ ), also apparent in the overall mean velocity (Figure 3C; WT: $3.34 \pm 0.29 \mathrm{~cm} / \mathrm{s}$, GluN2B KI: $2.66 \pm 0.18$ $\mathrm{cm} / \mathrm{s}$ ). The observed normal basal anxiety levels concur with earlier findings in the open field analysis and the same innate fear reaction to trimethyl-thiazoline (TMT) (Halt et al., 2012).

Learning and memory in contextual fear conditioning is not affected in GluN2B KI mice

With basal anxiety levels not being affected in the GluN2B KI mice (Halt et al., 2012) (Figure 3), we investigated the role of the CaMKII/GluN2B interaction in contextual fear conditioning. The experimentally naïve mice were placed in the conditioning chamber and after a 3 min habituation period trained with five consecutive foot shocks $(0.75 \mathrm{~mA}, 1 \mathrm{~s}$ duration; aversive unconditioned stimulus). The GluN2B KI mice learned to the same extent and at the same speed as their WT litter-matched controls (Figure 4A, C). A total of four independent cohorts were trained. To be able to distinguish possible differences between memory recall and consolidation, two cohorts were tested after 4 days (Figure 4B) and the other two cohorts after 14 days (Figure 4D). For the probe tests (after 4 or 14 days) the mice were placed back for 5 min into the conditioning chamber and the freezing response to the context was measured. There was no difference in the average time WT and KI mice spent freezing during either the 4 (WT: $51.11 \pm 3.37 \%$, KI: $52.23 \pm 3.77 \%$ ) or 14 days (WT: $70.48 \pm 4.75 \%$, KI: $67.51 \pm$ $3.33 \%$ ) probe test.

Contextual fear conditioning performance is independent of the stimulus strength

CaMKII T286A mutant mice have impaired contextual short-term memory (STM) and long-term memory (LTM) formation after a single or three tone-shock pairings, while contextual STM and LTM formation after five pairings are unaffected (Irvine et al., 2011; Irvine et al., 2005). To exclude the possibility that the GluN2B KI mice were over trained with five consecutive foot shocks $(0.75 \mathrm{~mA}$, $1 \mathrm{~s}$ duration) and potential cognitive deficits masked, we also tested two milder contextual fear conditioning paradigms. 
A Training

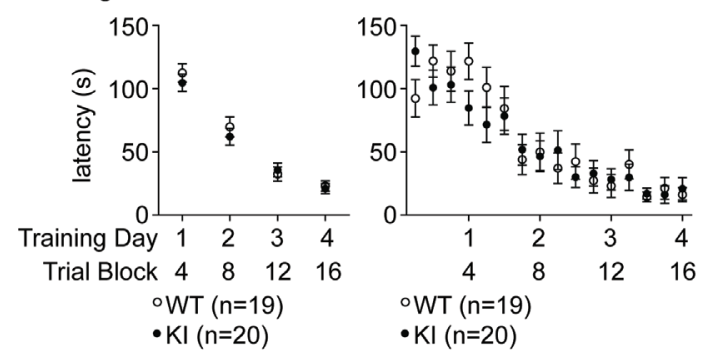

B 1 d probe trial
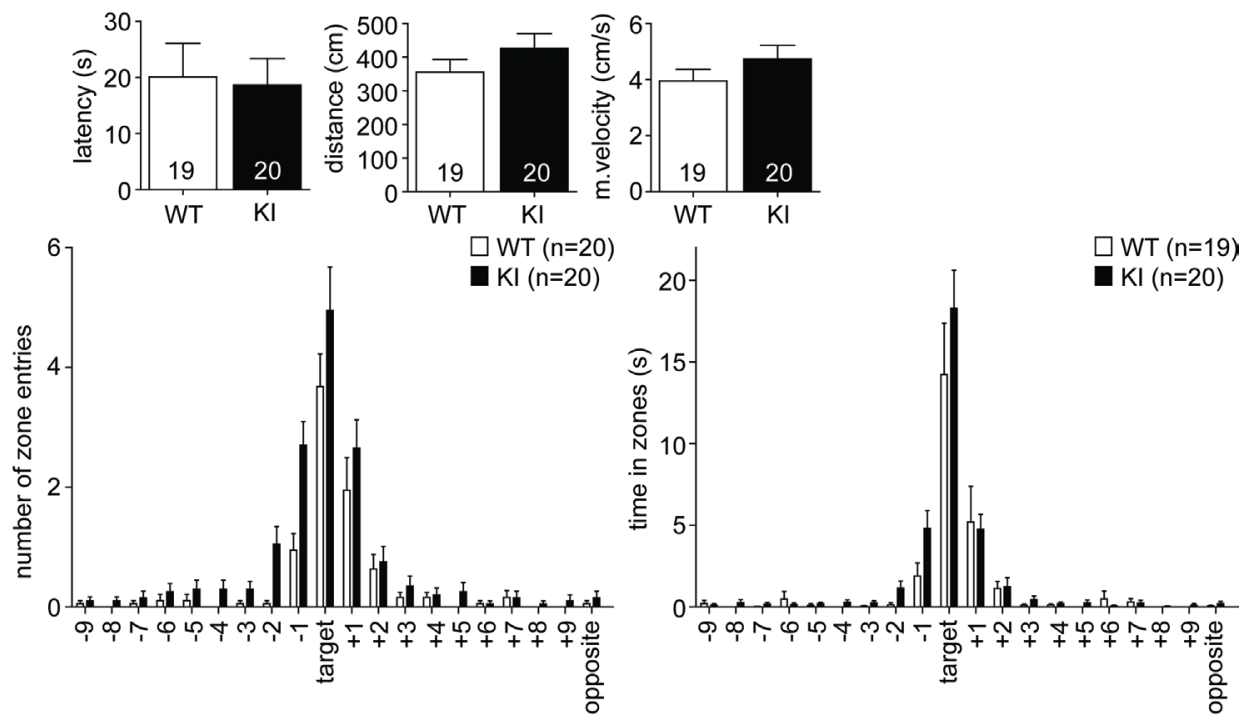

\section{7 d probe trial}
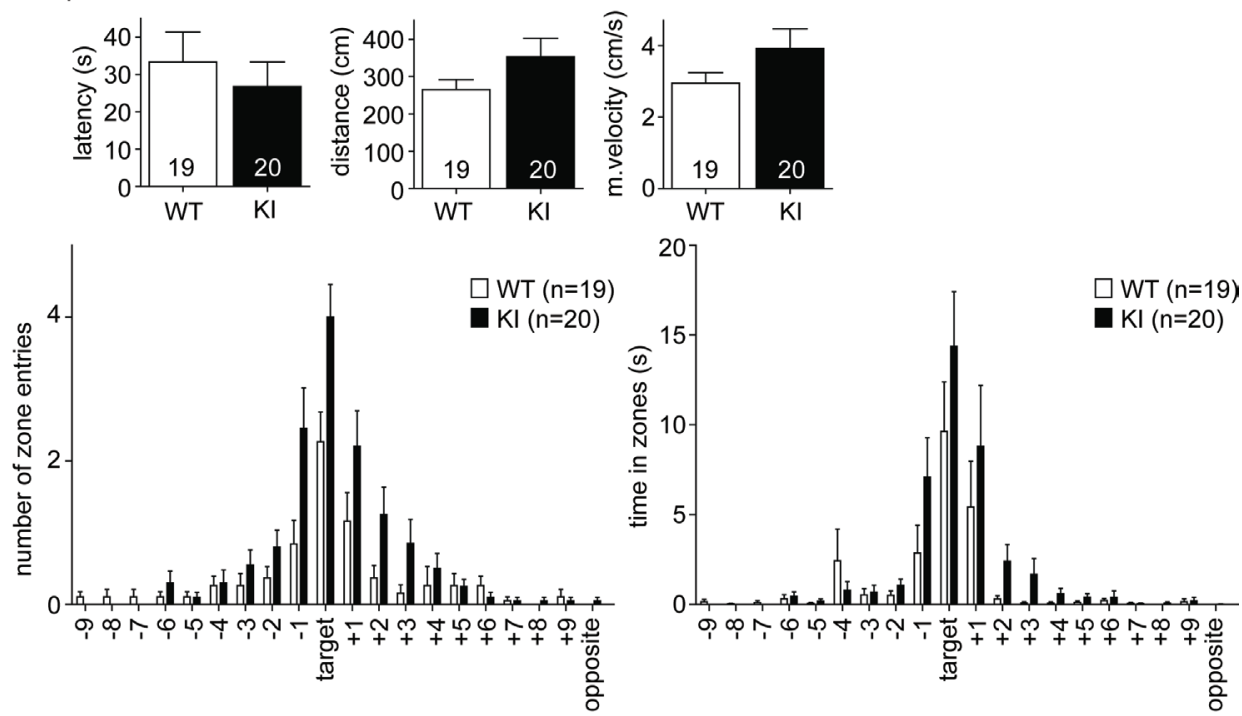

Figure 2. Spatial learning and memory is unaffected in the Barnes maze. (A) The escape latency for both genotypes decreases equally over the 16 training trials and saturates on the fourth day (left panel depicts average latencies over each of the 4 training days whereas right panel shows averages for each individual trial). (B) The primary escape latency during the probe test 1 day after the last training session is not different. KI mice search like the WT mice preferentially in and around the target area for the escape box (bottom panels). The covered distance (middle) and mean velocity (right) is slightly, but not significantly increased in KI mice. (C) The probe test 7 days after the last training session shows, like the 1 day test, no difference in the avg. primary escape latency (left) and the KI mice again exhibited the tendency to increased covered distance (middle) and mean velocity (right). Both genotypes searched in the right location in and around the target area (bottom panels). The same two independent cohorts, each consisting of 10 WT and 10 GluN2B KI mice, were tested in the Barnes maze followed by the MWM. Data are presented as Mean \pm SEM. 
A

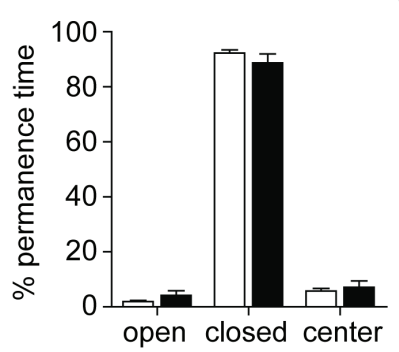

B

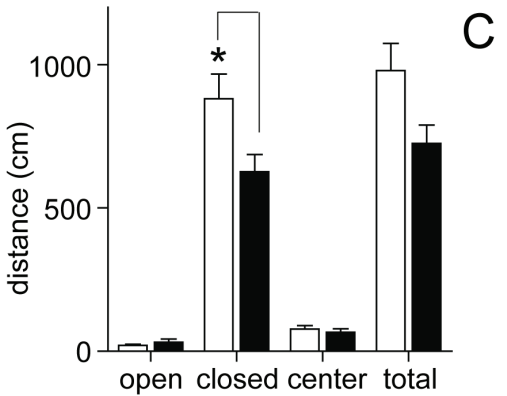

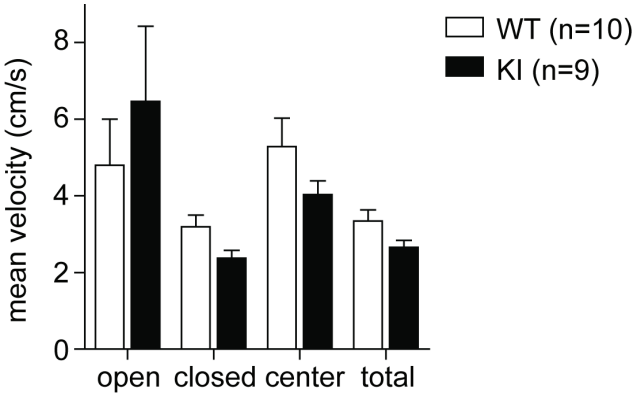

Figure 3. Basal anxiety levels in the GluN2B KI mice are normal. (A) The \% of time the mice spent in the open and closed arms as well as the center is not different between WT and KI. (B) Both genotypes cover the same minimal distances in the open arms but WT mice cover greater distances than $\mathrm{KI}$ mice in the closed arms. (C) The overall mean velocity is not different between both genotypes, while the WT mice show a slightly increased mean velocity in the closed arm coinciding with the longer covered distance. One cohort of 10 WT and 9 GluN2B $\mathrm{KI}$ mice was tested. The same cohort was subsequently used for the milder three shock fear conditioning paradigm (Figure 5A-E). Data represent Mean \pm SEM.

A

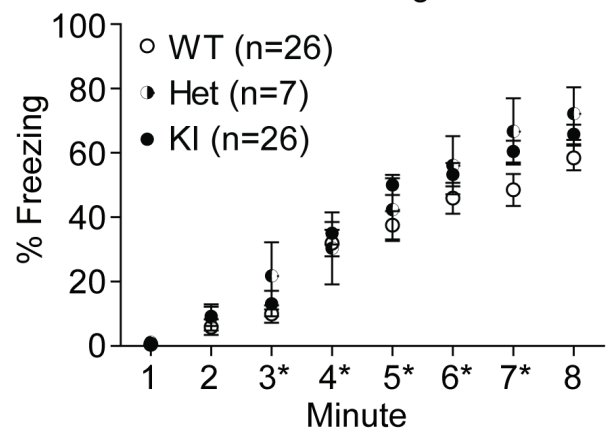

C

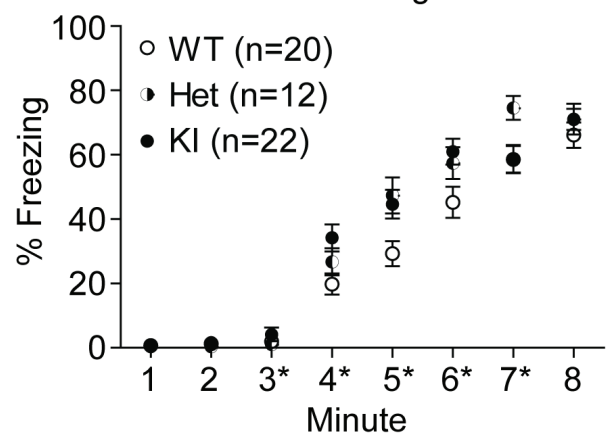

$\mathrm{B}$

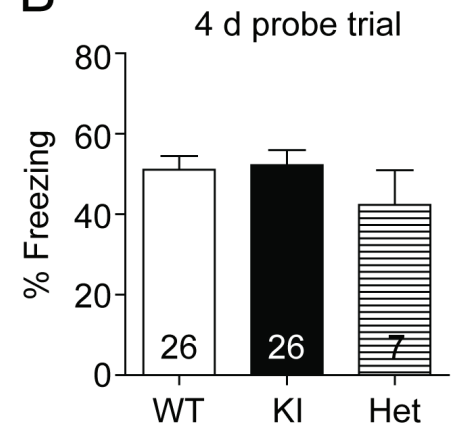

D

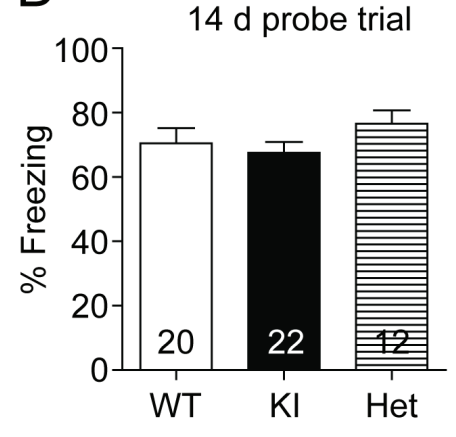

Figure 4. Contextual fear conditioning and memory is unaffected in GluN2B KI mice. Fear conditioning was evaluated 4 days after training of two different cohorts of naïve litter-matched WT, heterozygous, and GluN2B KI mice (12-14 WT and KI mice, and 3-4 heterozygous mice per cohort) and 14 days after training with yet another two different cohorts of naïve litter-matched WT, heterozygous, and GluN2B KI mice (10 WT mice, 10-12 KI mice, and 5-7 heterozygous mice per cohort). (A, C) After the 3 min habituation phase, 5 shocks (0.75 mA, $1 \mathrm{~s}$ ) were delivered at the end of $3^{\text {rd }}, 4^{\text {th }}, 5^{\text {th }}, 6^{\text {th }}$ and $7^{\text {th }}$ minute (asterisks). The increase in the fraction of time spent freezing during conditioning is not different between the GluN2B KI, heterozygous, and WT mice. (B, D) All genotypes also display a comparable fraction of time freezing during the 4 day and the 14 day probe test. Data represent percentage freezing (Mean \pm SEM). 
During the first paradigm, after two days of 3 min pre exposure to the conditioning chamber, 3 shocks $(0.5 \mathrm{~mA}, 1 \mathrm{~s})$ were delivered on day 3 at the end of the $3^{\text {rd }}, 4^{\text {th }}$ and $5^{\text {th }}$ minute. Conditioning and memory tested after 4 days (WT: $53.82 \pm 3.55 \%$, KI: $53.55 \pm 6.10 \%$ ) were unaffected (Figure 5A, B). When the mice were exposed to a different context in the same chamber and room 1 day later, the time spent freezing was reduced, similar to pre-conditioning levels, and did not differ between the two genotypes (Figure 5C; WT: $13.33 \pm$ $3.20 \%$, KI: $18.90 \pm 2.55 \%$ ). Long term memory was tested with the same cohort 11 days after training (Figure 5D) and like the 4 day test showed no difference (WT: $47.63 \pm 4.60 \%$, KI: $53.08 \pm 6.60 \%$ ). Figure $5 \mathrm{E}$ depicts an overview of the experiment.

In addition, another cohort of GluN2B KI and WT mice were trained over multiple days. The mice were pre exposed to the context on day 1 for $10 \mathrm{~min}$ and trained on the following 4 days with one foot shock (each $0.75 \mathrm{~mA}, 1 \mathrm{~s}$ ) per day (Figure 5F). Again no learning or memory deficit, which was tested 6 (WT: $75.52 \pm 4.64 \%$, GluN2B KI: $62.69 \pm 6.21$ ) and 8 days (WT: $64.75 \pm 5.68 \%$, KI: $59.06 \pm$ $7.56 \%$ ) after training, was observed. When the mice were exposed to a different context in the same chamber and room on day 12 , 7 days after the last training, both genotypes exhibited reduced freezing levels (WT: $25.56 \pm 5.85 \%$, KI: $22.09 \pm 6.93 \%$ ) similar to those observed before conditioning.

\section{Dataset 1. Data sets for behavioral tasks in wild type and GlunN2BKI mice}

\section{http://dx.doi.org/10.5256/f1000research.4660.d34165}

The raw data tables show the performances of the individual wild type and GlunN2B KI mice in the various behavioral tasks, which are represented in the text and figures as mean \pm the standard error of the mean (SEM). Data sets for 'MWM data', 'Barnes maze data',

'Elevated plus maze data set' and 'Contextual fear conditioning data set' are shown. Specific information can be found in text file.

\section{Discussion}

CaMKII and the NMDAR are crucial not only for hippocampal LTP but also for hippocampus dependent spatial learning and memory formation. In a number of studies CaMKII $\alpha \mathrm{KO}$ and mutant mice

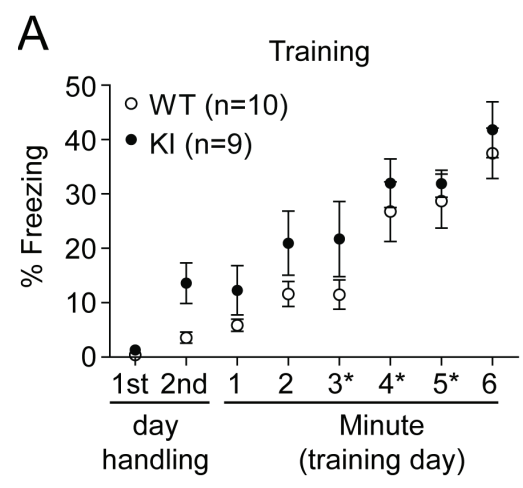

B
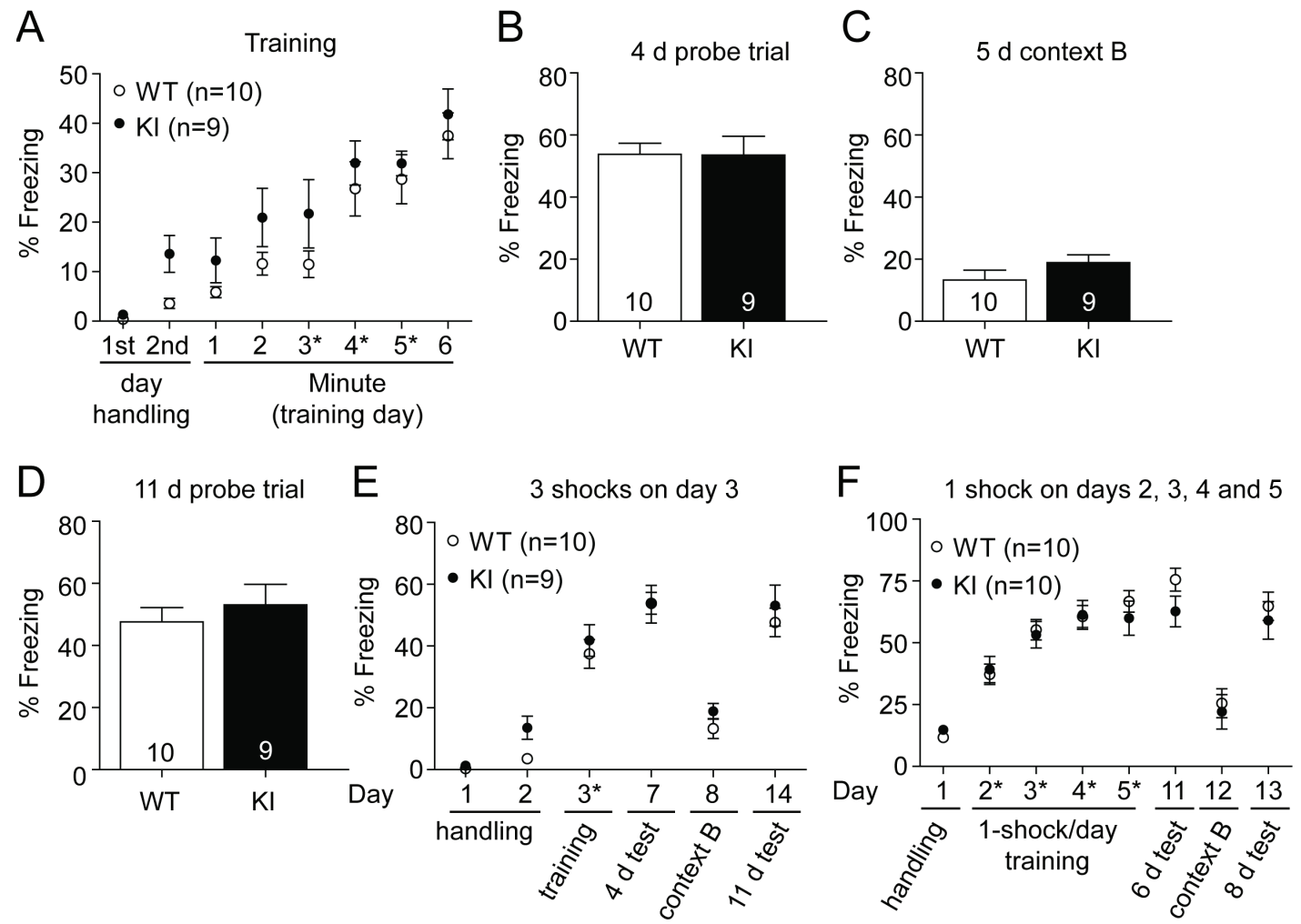

Figure 5. Contextual fear conditioning with milder conditioning is unaffected in GluN2B KI mice. One cohort of litter-matched GluN2B KI and WT mice (9-10 mice per genotype, previously tested in the EPM) was fear conditioned with three shocks on a single day and a different cohort of naïve litter-matched GluN2B KI and WT mice (10 mice per genotype) was fear conditioned with four shocks over a period of 4 days. (A) $\mathrm{KI}$ and WT mice acquired to the same extent fear conditioning as indicated by the time spent freezing after three consecutive mild foot shocks $(0.5 \mathrm{~mA}, 1 \mathrm{~s})$ at the end of the $3^{\text {rd }}, 4^{\text {th }}$ and $5^{\text {th }}$ minute (asterisks). (B, D) The time spent freezing during recall of context after $4 \mathrm{~d}$ and $11 \mathrm{~d}$ is not different between genotypes. (C) Exposure to a different context 5 days after training shows pre-conditioning freezing levels for both genotypes. (E) Summary plot of the experimental data from A-D. (F) Summary plot of the experimental data of the 4 day training (1 shock, $0.75 \mathrm{~mA}, 1 \mathrm{~s}$ per day) experiment. WT and KI mice show comparable learning curves during the $4 \mathrm{~d}$ conditioning and similar contextual memory when tested 6 and 8 days later. Exposure to a different context in the same room and chamber, $7 \mathrm{~d}$ after the last training day, revealed again pre-conditioning freezing levels. Data represent percentage freezing (Mean $\pm S E M$ ). 
displayed learning deficits, notably mainly in aversively motivated tasks (Elgersma et al., 2002; Giese et al., 1998; Irvine et al., 2005; Silva et al., 1992), while appetitive learning was unaffected (Carvalho et al., 2001). Moreover, the regulation of expression or activity level of CaMKII $\alpha$ seems to have an emotional component and especially impact emotional and anxiety-like behavior and learning. CaMKII $\alpha$ heterozygous KO mice show a decreased freezing in fear conditioning induced by an electric foot shock and are more active in the open field suggesting decreased anxietyrelated behaviors (Chen et al., 1994). Consistently, transgenic mice overexpressing CaMKII $\alpha$ exhibit an increase in anxiety-like behaviors in open field, light-dark transition, and elevated zero maze (Hasegawa et al., 2009). CaMKII $\alpha$ T286A mutant mice, which are deficient in autonomous and thereby overall CaMKII activity, spend more time in and entered more often the open arm in the EPM and generally react with hyperactivity to novel stimuli that could be perceived as potentially threatening (Easton et al., 2011). However, the behavior in the non-threatening neutral environment of the home cage is normal (Easton et al., 2011), in accordance with an impaired learning in MWM and fear conditioning (Giese et al., 1998; Irvine et al., 2005) but a normal appetitive instrumental conditioning (Carvalho et al., 2001). Results in our study concur with these findings and argue for the specific importance of CaMKII binding to GluN2B in aversive and more demanding spatial learning task of the MWM, with the less threatening and stressful Barnes maze task being unaffected in the KI mice. Contextual fear conditioning and memory was surprisingly not affected in the GluN2B KI mice. We assume that this discrepancy is due to the higher demands of the MWM task and the differential regulation of spatial and contextual LTM formation (Mizuno \& Giese, 2005).

Learning during massed training sessions, i.e., when training trials are given in short order on a single day, generally results in lower levels of learning than spaced training over a period of several days. For instance, in the MWM rats showed faster and better acquisition during spaced (16 trials over 4 days) than massed training (16 trials in 1 day) as well as better memory formation (Commins et al., 2003). During contextual fear conditioning $1 \mathrm{~h}$ spaced training also results in better memory formation than massed training, while cued fear conditioning is unaffected (Scharf et al., 2002). Likely because of the more demanding task of massed training, which requires information being stored during a shorter time period than in spaced training, the GluN2B KI mice revealed a mild learning deficit compared to WT mice in the 1 day paradigm (Figure 1) when they did not in the 6 day MWM training protocol (Halt et al., 2012). Figure 1D shows that there is no difference in the swim speed between WT and KI mice, which together with the increased covered distance of the KI mice during the last two trials (Figure 1C) argues against the differences in agility and fatigue in the GluN2B KI. The increased covered distance shows that the KI mice have to swim longer and cover a greater distance in order to find the platform during the later trials, further supporting the extended primary escape latency (Figure 1B) and therefore the KI learning deficit. The learning deficit in the 1 day paradigm suggests that the learning capacity over a more limited time period is reduced in GluN2B KI mice. In addition, the elevated stress level during the massed training in the 1 day protocol could affect learning in the GluN2B KI mice more than in WT contributing to the differential outcome.
The GluN2B KI phenotype is similar to alpha and delta CREB KO mice, which are impaired in massed but not in spaced MWM learning and contextual fear conditioning (Kogan et al., 1997). The improvement in memory after spaced learning is also mimicked in acute hippocampal slices where successive spaced theta burst stimulation resulted in enhanced previously saturated LTP (Kramar et al., 2012). In the study by Kramar et al. the induction of LTP in a subset of synapses during the first theta burst train primed the initially unresponsive neighbors (probably in a translation-dependent manner, since the two stimulations have to be spaced $1 \mathrm{~h}$ apart; see also (Scharf et al., 2002)), resulting in potentiation after stimulation with the second theta burst train. This mechanism will probably be especially important in cases of impaired LTP induction or expression like in our GluN2B KI mice where various forms of LTP were reduced by $\sim 50 \%$ (Halt et al., 2012).

The Barnes maze is a demanding spatial task using visual cues in the room for navigation, which is in that regard similar to the MWM. One major difference between these two spatial learning paradigms is probably the amount of stress to which animals are exposed. The unaffected performance of the GluN2B KI mice in the less stressful Barnes Maze is in line with the known importance of CaMKII selectively in aversive rather than appetitive motivated spatial and contextual learning paradigms (Elgersma et al., 2002; Giese et al., 1998; Irvine et al., 2005; Silva et al., 1992). However, further potential differences include sensory processes and response requirements, which cannot be excluded as a reason for the deficit in massed MWM learning compared to no deficit in the Barnes maze (Figure 2).

Fear conditioning, on the other hand, creates a high level of anxiety. Compared to spatial learning paradigms like the MWM, the contextual conditioning only requires memorization of a far less complex environment, which only has to be recognized and does not require navigation and localization of a certain target. Additionally, at the beginning of the conditioning the mice have time to explore and form a spatial map without being stressed or more anxious than during the normal exposure to a novel environment, before the first shock is delivered at the end of the $3^{\text {rd }}$ minute. During the milder conditioning paradigm (Figure 5) the mice were pre-exposed to the shocking chamber on the previous day, which allowed the formation of an even better spatial representation (Fanselow, 2000; Frankland et al., 2004; Hu et al., 2007). This lack of a demanding spatial learning requirement and possible formation of contextual memory during still low stress levels could explain the normal conditioning and contextual memory (Figure 4 and Figure 5) compared to the moderate learning deficit observed during massed MWM training (Figure 1). In addition, fear conditioning in general constitutes a very strong learning paradigm, which might override and mask any mild learning deficits because of its vigor even in the mildest form tested here. In support of this idea the five tone-shock pairings allow full fear conditioning in CaMKII T286A mutant mice when one and three pairings do not (Irvine et al., 2011; Irvine et al., 2005). Accordingly, the strength of conditioning can mask learning deficits, and for GluN2B KI mice that might even be the case for single shock experiments. Spatial and contextual LTM formation is differently regulated. There are not only divergent regional requirements within the hippocampus, 
but also the control of gene transcription varies between spatial and contextual LTM formation (Mizuno \& Giese, 2005). Accordingly, MWM and fear conditioning could depend on molecular mechanisms that vary in detail even though both learning paradigms require CaMKII.

Contrasting CaMKII $\alpha$ heterozygous KO, T286A KI mice, or transgenic mice overexpressing CaMKII $\alpha$, the GluN2B KI mice display no change in basal anxiety levels or anxiety-like behaviors. They show avoidance of the open arms in the EPM (Figure 3), behavior in the open field (Halt et al., 2012), and reaction to TMT (the anxiogenic compound in fox urine) (Halt et al., 2012), a measure of innate fear, that are comparable to WT mice. Thus it appears that CaMKII $\alpha$ affects fear behavior independent of its binding to GluN2B.

Our study suggests a specific requirement for the activity-dependent interaction of CaMKII with the NMDAR during the acquisition of more elaborate spatial learning tasks under modestly aversive, stressful conditions. The results argue not only for a role of CaMKII binding to GluN2B during consolidation (Halt et al., 2012), but also for learning, which becomes obvious under the here applied more demanding MWM conditions. The less stressful Barnes maze neither results in a consolidation deficit nor is the learning itself affected. In addition, the less demanding but more potent contextual fear conditioning and memory was surprisingly normal. Whether reduced recall of the MWM task 1 and 7 days after single day training reflects reduced learning, reduced memory consolidation, or both cannot be answered at this point.

\section{Data availability}

F1000Research: Dataset 1. Data sets for behavioral tasks in wild type and GlunN2BKI mice, 10.5256/f1000research.4660.d34165 (Stein et al., 2014).

\section{Author contributions}

ISS and JWH designed the experiments. ISS with help from MSD carried out the experiments. ISS and JWH prepared the manuscript. All authors approved the final content of the manuscript.

\section{Competing interests}

No competing interests were disclosed.

\section{Grant information}

This work was supported by NIH grants NS046450 and NS078792

The funders had no role in study design, data collection and analysis, decision to publish, or preparation of the manuscript.

\section{Acknowledgements}

We thank the Personnel of the UC Davis Mouse Behavioral Assessment Lab, where all behavioral tests were conducted, for their assistance and help with data analysis, as well as Claire M. Koenig for training in the Barnes maze. We thank Dr. Karl-Peter Giese (Kings College, London, UK) for reading an earlier version of the manuscript.
Barria A, Malinow R: NMDA receptor subunit composition controls synaptic plasticity by regulating binding to CaMKII. Neuron. 2005; 48(2): 289-301. PubMed Abstract | Publisher Full Text

Bayer KU, De Koninck P, Leonard AS, et al:: Interaction with the NMDA receptor locks CaMKII in an active conformation. Nature 2001; 411(6839): 801-805. PubMed Abstract | Publisher Full Text

Berta S, Gert L, Harald H, et al.: Barnes maze, a useful task to assess spatial reference memory in the mice. Protoc exch. 2007.

Publisher Full Text

Carvalho MO, Silva JA, Balleine WB: Evidence of selective learning deficits on tests of pavlovian and instrumental conditioning in $\alpha$-CaMKII T286 mutant mice. Human Sciences Press, New York, NY ETATS-UNIS. Int J Comp Psychol. 2001; 14(3): 161-174

Reference Source

Chen C, Rainnie DG, Greene RW, et al:: Abnormal fear response and aggressive behavior in mutant mice deficient for alpha-calcium-calmodulin kinase II.

Science. 1994; 266(5183): 291-294.

PubMed Abstract | Publisher Full Tex

Commins S, Cunningham L, Harvey D, et al.: Massed but not spaced training impairs spatial memory. Behav Brain Res. 2003; 139(1-2): 215-223.

PubMed Abstract | Publisher Full Text

Curzon P, Rustay NR, Browman KE: Cued and Contextual Fear Conditioning for Rodents. In Buccafusco, J.J. (ed), Boca Raton (FL). Meth Behav Anal Neurosci. 2009; 19-37.

PubMed Abstract | Publisher Full Tex

Easton AC, Lucchesi W, Schumann G, et al:: $\alpha$ CaMKII autophosphorylation controls exploratory activity to threatening novel stimuli. Neuropharmacology. 2011; 61(8): 1424-1431.

PubMed Abstract | Publisher Full Text
Elgersma Y, Fedorov NB, Ikonen S, et al.: Inhibitory autophosphorylation of CaMKII controls PSD association, plasticity, and learning. Neuron. 2002; 36(3) 493-505.

PubMed Abstract | Publisher Full Text

Fanselow MS: Contextual fear, gestalt memories, and the hippocampus. Behav Brain Res. 2000; 110(1-2): 73-81.

PubMed Abstract | Publisher Full Text

Frankland PW, Josselyn SA, Anagnostaras SG, et al:: Consolidation of CS and US representations in associative fear conditioning. Hippocampus. 2004; 14(5): $557-569$.

PubMed Abstract | Publisher Full Text

Giese KP, Fedorov NB, Filipkowski RK, et al:: Autophosphorylation at Thr286 of the alpha calcium-calmodulin kinase II in LTP and learning. Science. 1998; 279(5352): 870-873.

PubMed Abstract | Publisher Full Text

Gruart A, Muñoz MD, Delgado-Garcia JM: Involvement of the CA3-CA1 synapse in the acquisition of associative learning in behaving mice. $J$ Neurosci. 2006; 26(4): 1077-1087.

PubMed Abstract | Publisher Full Text

Halt AR, Dallapiazza RF, Zhou Y, et al:: CaMKII binding to GluN2B is critical during memory consolidation. EMBO J. 2012; 31(5): 1203-1216.

PubMed Abstract | Publisher Full Text | Free Full Text

Hasegawa S, Furuichi T, Yoshida T, et al.: Transgenic up-regulation of alphaCaMKII in forebrain leads to increased anxiety-like behaviors and aggression Mol Brain. 2009; 2: 6.

PubMed Abstract | Publisher Full Text | Free Full Text

$\mathrm{Hu} \mathrm{H}$, Real E, Takamiya $\mathrm{K}$, et al:: Emotion enhances learning via norepinephrine regulation of AMPA-receptor trafficking. Cell. 2007; 131(1): 160-173.

PubMed Abstract | Publisher Full Tex 
Irvine EE, Danhiez A, Radwanska K, et al.: Properties of contextual memory formed in the absence of $\alpha$ CaMKII autophosphorylation. Mol Brain. 2011; 4: 8 . PubMed Abstract | Publisher Full Text | Free Full Text

Irvine EE, Vernon J, Giese KP: AlphaCaMKII autophosphorylation contributes to rapid learning but is not necessary for memory. Nat Neurosci. 2005; $8(4)$ : 411-412.

PubMed Abstract | Publisher Full Text

Kessels HW, Malinow R: Synaptic AMPA receptor plasticity and behavior. Neuron. 2009; 61(3): 340-350.

PubMed Abstract | Publisher Full Text | Free Full Text

Kogan JH, Frankland PW, Blendy JA, et al:: Spaced training induces normal longterm memory in CREB mutant mice. Curr Biol 1997; 7(1): 1-11.

PubMed Abstract | Publisher Full Text

Kramár EA, Babayan AH, Gavin CF, et al:: Synaptic evidence for the efficacy of spaced learning. Proc Natl Acad Sci U S A. 2012; 109(13): 5121-5126.

PubMed Abstract | Publisher Full Text | Free Full Text

Lengyel I, Voss K, Cammarota M, et al:: Autonomous activity of CaMKII is only transiently increased following the induction of long-term potentiation in the rat hippocampus. Eur J Neurosci. 2004; 20(11): 3063-3072.

PubMed Abstract | Publisher Full Text

Leonard AS, Lim IA, Hemsworth DE, et al:: Calcium/calmodulin-dependent protein kinase II is associated with the $\mathrm{N}$-methyl-D-aspartate receptor. Proc Natl Acad Sci U S A. 1999; 96(6): 3239-3244.

PubMed Abstract | Publisher Full Text

Lisman J, Schulman $\mathrm{H}$, Cline $\mathrm{H}$ : The molecular basis of CaMKII function in synaptic and behavioural memory. Nat Rev Neurosci. 2002; 3(3): 175-190. PubMed Abstract | Publisher Full Text

Martin SJ, Grimwood PD, Morris RG: Synaptic plasticity and memory: an evaluation of the hypothesis. Annu Rev Neurosci. 2000; 23: 649-711. PubMed Abstract | Publisher Full Text

Mizuno K, Giese KP: Hippocampus-dependent memory formation: do memory type-specific mechanisms exist? J Pharmacol Sci. 2005; 98(3): 191-197. PubMed Abstract | Publisher Full Text

Morris RG: NMDA receptors and memory encoding. Neuropharmacology. 2013; 74: $32-40$

PubMed Abstract | Publisher Full Text

Neves G, Cooke SF, Bliss TV: Synaptic plasticity, memory and the hippocampus: a neural network approach to causality. Nat Rev Neurosci. 2008; 9(1): 65-75. PubMed Abstract | Publisher Full Text

Otmakhov N, Tao-Cheng JH, Carpenter S, et al:: Persistent accumulation of calcium/calmodulin-dependent protein kinase II in dendritic spines after induction of NMDA receptor-dependent chemical long-term potentiation. $J$ Neurosci. 2004; 24(42): 9324-9331.

PubMed Abstract | Publisher Full Text
Ouyang Y, Kantor D, Harris KM, et al.: Visualization of the distribution of autophosphorylated calcium/calmodulin-dependent protein kinase II after tetanic stimulation in the CA1 area of the hippocampus. $J$ Neurosci. 1997; 17(14): 5416-5427.

PubMed Abstract

Ouyang Y, Rosenstein A, Kreiman G, et al:: Tetanic stimulation leads to increased

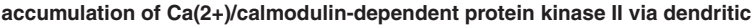
protein synthesis in hippocampal neurons. J Neurosci. 1999; 19(18): 7823-7833. PubMed Abstract

Rose J, Jin SX, Craig AM: Heterosynaptic molecular dynamics: locally induced propagating synaptic accumulation of CaM kinase II. Neuron. 2009; 61(3): 351-358.

PubMed Abstract | Publisher Full Text | Free Full Text

Scharf MT, Woo NH, Lattal KM, et al:: Protein synthesis is required for the enhancement of long-term potentiation and long-term memory by spaced training. J Neurophysiol. 2002; 87(6): 2770-2777.

PubMed Abstract

Silva AJ, Paylor R, Wehner JM, et al.: Impaired spatial learning in alpha-calciumcalmodulin kinase II mutant mice. Science. 1992; 257(5067): 206-211. PubMed Abstract | Publisher Full Text

Stein IS, Donaldson MS, Hell JW: Data sets for behavioral tasks in wild type and GlunN2BKI mice. F1000Research. 2014.

Data Source

Strack S, Colbran RJ: Autophosphorylation-dependent targeting of calcium calmodulin-dependent protein kinase II by the NR2B subunit of the N-methylD-aspartate receptor. J Biol Chem 1998; 273(33): 20689-20692.

PubMed Abstract | Publisher Full Text

Strack S, McNeill RB, Colbran RJ: Mechanism and regulation of calcium/ calmodulin-dependent protein kinase II targeting to the NR2B subunit of the N-methyl-D-aspartate receptor. J Biol Chem. 2000; 275(31): 23798-23806. PubMed Abstract | Publisher Full Text

Tan SE, Liang KC: Spatial learning alters hippocampal calcium/calmodulindependent protein kinase II activity in rats. Brain Res. 1996; 711(1-2): 234-240. PubMed Abstract | Publisher Full Tex

Whitlock JR, Heynen AJ, Shuler MG, et al.: Learning induces long-term potentiation in the hippocampus. Science. 2006; 313(5790): 1093-1097. PubMed Abstract | Publisher Full Text

Zhang YP, Holbro N, Oertner TG: Optical induction of plasticity at single synapses reveals input-specific accumulation of alphaCaMKII. Proc Natl Acad Sci U S A. 2008; 105(33): 12039-12044.

PubMed Abstract | Publisher Full Text | Free Full Text

Zhou Y, Takahashi E, Li W, et al:: Interactions between the NR2B receptor and CaMKII modulate synaptic plasticity and spatial learning. J Neurosci. 2007: 27(50): 13843-13853.

PubMed Abstract | Publisher Full Text 


\section{Open Peer Review}

\section{Current Peer Review Status:}

\section{Version 1}

Reviewer Report 29 September 2014

https://doi.org/10.5256/f1000research.4981.r6236

(C) 2014 Pérez-Otaño I. This is an open access peer review report distributed under the terms of the Creative Commons Attribution License, which permits unrestricted use, distribution, and reproduction in any medium, provided the original work is properly cited.

\section{Isabel Pérez-Otaño}

Laboratorio de Neurobiología Celular, Departamento de Neurociencias, Centro de Investigacion en Medicina Aplicada, Pamplona, Spain

The manuscript by Stein et al. expands previous work from the same group characterizing the learning abilities of CamKII knock-in mice (Halt et al., 2012). The mice carry two point mutations that impair the binding of CamKII to the NMDA receptor subunit GluN2B, and were shown to exhibit deficits in memory recall in the Morris Water maze (MWM). Here, the authors present an extended and carefully performed behavioral analysis. Their new results show that spatial learning in the MWM is impaired when 12 training trials are compressed in a single day. In contrast, the previous study showed that spatial learning was normal when training was conducted over 6 consecutive days ( 2 trials per day). The different outcome is attributed to the increased cognitive demands and higher stress levels posed by massed training. The paper is wellwritten and clearly presented, and the Methods are described with enough detail.

\section{Comments:}

1. The deficits in massed spatial learning are only detectable in the last two trials. Do the authors have an explanation? Could the delay be related to a defect in an early phase of consolidation, in line with the hypothesis previously proposed by the authors (Halt et al., 2012)?

2. It might be nice to see whether memory consolidation is impaired in other hippocampaldependent tests not involving stress. For instance, the novel object recognition test that can be performed in a brief period of time and would additionally permits the assessment of memory recall at shorter time intervals after initial learning.

Competing Interests: No competing interests were disclosed.

I confirm that I have read this submission and believe that I have an appropriate level of expertise to confirm that it is of an acceptable scientific standard. 
Reviewer Report 26 August 2014

https://doi.org/10.5256/f1000research.4981.r5919

(C) 2014 Bayer K. This is an open access peer review report distributed under the terms of the Creative Commons Attribution License, which permits unrestricted use, distribution, and reproduction in any medium, provided the original work is properly cited.

\section{Karl-Ulrich Bayer}

Department of Pharmacology, University of Colorado Denver, Aurora, CO, USA

Summary: This study substantially extends the previous behavioral analysis of a mouse line with mutant GluN2B that is incapable of CaMKII binding. Individually, both GluN2B and CaMKII are critically involved in regulating synaptic plasticity and learning and memory. Previous studies from the same lab showed that the mutant GluN2B KI mice have impaired hippocampal CA1 LTP (reduced to $~ 50 \%$ ) and impaired recall during the consolidation phase of a Morris water maze (MWM) task ${ }^{1}$. Here, learning impairments were found in a modified MWM task that involves massed learning during day 1 . All other learning paradigms tested here or previously were normal. Basal behavior was also extensively evaluated, and was found to be normal in all tasks tested here or previously.

Evaluation: The manuscript is very well written. The experiments and the analyses are solid. The interpretation and discussion of the results are both careful and insightful. Overall, it can be very reasonably concluded that learning requires the CaMKII/GluN2B interaction only when the learning task is rather difficult and/or involves some stress (such as in a water maze), consistent also with impaired but not abolished LTP in these mice.

Comments: The conclusions from this study may also inform potential future behavioral studies on these mice. For instance, while the GluN2B KI mice were normal in multiple variations of contextual fear conditioning, the contextual part of the task was made rather easy in all paradigms tested. However, even with shorter exposure to the context, fear conditioning may still be too easy of a learning task to reveal any differences in the GluN2B mice. Thus, while such future studies may be interesting, either outcome would still be consistent with the conclusions reached here.

The behavioral analyses of the GluN2B KI mice were done specifically in order to evaluate the impact of the LTP impairments in these mice. When comparing the GluN2B KI mice with CaMKII T286A or CaMKII knock-out mice in other behavioral tasks in future studies, it may have to be taken into account that the GluN2B KI mice are impaired only in LTP, while the CaMKII mutant mice are additionally impaired in LTD.

One point in which my opinion differs is within the introduction, specifically regarding the statement that "auto-phosphorylation on T286 is required for effective binding of CaMKII to GluN2B". The cited references could indeed be interpreted support this statement ${ }^{2}{ }^{3}$. However, newer data indicate that the increased binding observed after ATP addition was largely caused by direct nucleotide binding to the kinase, rather than by auto-phosphorylation ${ }^{456}$. 
Notably, this point does not affect the validity of any conclusions reached in the manuscript. However, it may significantly mislead the reader about the larger context of CaMKII in synaptic plasticity. Recently, we have shown that CaMKII T286 phosphorylation is required not only for LTP, but also for $\mathrm{LTD}^{7}$. Prior to this, other recent evidence had already suggested a more prolonged T286 phosphorylation after LTD than after LTP8 910 (for review see Coultrap \& Bayer, 2012 ${ }^{11}$ ). If T286 phosphorylation would induce the most effective CaMKII binding to GluN2B (as stated), binding would be expected to be more extensive after LTD compared to LTP. However, this does not appear to be the case ${ }^{9}$, and the CaMKII/GluN2B interaction contributes exclusively to the CaMKII functions in LTP but not in LTD ${ }^{1}$.

\section{References}

1. Halt AR, Dallpiazza RF, Zhou Y, Stein IS, et al.: CaMKII binding to GluN2B is critical during memory consolidation.EMBO J. 2012; 31 (5): 1203-1216 PubMed Abstract | Free Full Text | Publisher Full Text

2. Bayer KU, De Koninck $\mathrm{P}$, Leonard AS, Hell JW, et al.: Interaction with the NMDA receptor locks CaMKII in an active conformation.Nature. 2001; 411 (6839): 801-805 PubMed Abstract | Publisher Full Text

3. Strack S, Colbran RJ: Autophosphorylation-dependent targeting of calcium/ calmodulindependent protein kinase II by the NR2B subunit of the N-methyl- D-aspartate receptor.J Biol Chem . 1998; 273 (33): 20689-20692 PubMed Abstract | Publisher Full Text

4. Barcomb K, Coultrap SJ, Bayer KU: Enzymatic Activity of CaMKII Is Not Required for Its Interaction with the Glutamate Receptor Subunit GluN2B.Mol Pharmacol. 2013; 84: 834-843 PubMed Abstract | Free Full Text | Publisher Full Text

5. O'Leary H, Liu WH, Rorabaugh JM, Coultrap SJ, et al.: Nucleotides and phosphorylation bidirectionally modulate Ca2+/calmodulin-dependent protein kinase II (CaMKII) binding to the Nmethyl-D-aspartate (NMDA) receptor subunit GluN2B. J Biol Chem. 2011; 286 (36): 31272-31281 PubMed Abstract | Free Full Text | Publisher Full Text 6. Robison AJ, Bartlett RK, Bass MA, Colbran RJ: Differential modulation of Ca2+/calmodulindependent protein kinase II activity by regulated interactions with $\mathrm{N}$-methyl-D-aspartate receptor NR2B subunits and alpha-actinin.J Biol Chem. 2005; 280 (47): 39316-39323 PubMed Abstract | Publisher Full Text

7. Coultrap SJ, Freund RK, O'Leary H, Sanderson JL, et al.: Autonomous CaMKII mediates both LTP and LTD using a mechanism for differential substrate site selection.Cell Reports. 2014; 6 (3): 431437 PubMed Abstract | Free Full Text | Publisher Full Text

8. Lee SJ, Escobedo-Lozoya Y, Szatmari EM, Yasuda R: Activation of CaMKII in single dendritic spines during long-term potentiation.Nature. 2009; 458 (7236): 299-304 PubMed Abstract | Free Full Text | Publisher Full Text

9. Marsden KC, Shemesh A, Bayer KU, Carroll RC: Selective translocation of Ca2+/calmodulin protein kinase IIalpha (CaMKIIalpha) to inhibitory synapses.Proc Natl Acad Sci U S A. 2010; 107 (47): 20559-20564 PubMed Abstract | Free Full Text | Publisher Full Text

10. Mockett BG, Guevremont D, Wutte M, Hulme SR, et al.: Calcium/calmodulin-dependent protein kinase II mediates group I metabotropic glutamate receptor-dependent protein synthesis and long-term depression in rat hippocampus.J Neurosci. 2011; 31 (20): 7380-7391 PubMed Abstract | Publisher Full Text

11. Coultrap SJ, Bayer KU: CaMKII regulation in information processing and storage.Trends Neurosci. 2012; 35 (10): 607-618 PubMed Abstract | Free Full Text | Publisher Full Text 
Competing Interests: No competing interests were disclosed.

\section{I confirm that I have read this submission and believe that I have an appropriate level of expertise to confirm that it is of an acceptable scientific standard.}

Reviewer Report 22 August 2014

https://doi.org/10.5256/f1000research.4981.r5845

(C) 2014 Dell'Acqua M. This is an open access peer review report distributed under the terms of the Creative Commons Attribution License, which permits unrestricted use, distribution, and reproduction in any medium, provided the original work is properly cited.

\section{Mark L. Dell'Acqua}

Department of Pharmacology, University of Colorado Denver, Denver, CO, USA

This is an interesting article that provides additional, detailed behavioral analysis of hippocampaldependent spatial and contextual learning and memory performance of knock-in mice that are deficient in CaMKII binding to the GluN2B subunit of the NMDA-subtype ionotropic glutamate receptor. The current findings extend those of the authors in Halt et al. (2012) where spaced training over 6 days in the Morris Water Maze (MWM) revealed no deficits in spatial learning but did find significant deficits in consolidation of long-term memory probed several days after training in theses CaMKII binding-deficient GluN2B knock-in mice.

Interestingly, here, using a more intense and demanding one day, massed training version of the MWM, the authors now detect modest deficits in these GluN2B knock-in mice, not only in memory probed one day after training, but also in spatial learning measured on the day of training. However, other single day training spatial/contextual learning and memory tests, that are both more aversive but less spatially challenging (contextual fear conditioning) and less aversive but more spatially challenging (Barnes maze), did not reveal any difference in performance between WT and GluN2B knock-in mice. Thus, an important conclusion of this study is that increased postsynaptic targeting of CaMKII and the increased level of LTP ( $50 \%$; see Halt et al.) that are achieved through CaMKII binding to GluN2B are only required for spatial learning when the task is both fairly demanding and at least moderately aversive. These findings should give the field a heightened appreciation that highly-compartmentalized regulation of signaling pathways by postsynaptic protein-protein scaffolding interactions, such as achieved through CaMKII binding to GluN2B during LTP-induction, may not be absolutely essential for spatial learning and memory in general but may have evolved to allow animals to specifically sustain optimal spatial learning and memory capabilities even under demanding and stressful circumstances.

Overall, the manuscript is very well written and the data are rigorously analyzed and presented clearly.

Competing Interests: No competing interests were disclosed. 
I confirm that I have read this submission and believe that I have an appropriate level of expertise to confirm that it is of an acceptable scientific standard.

The benefits of publishing with F1000Research:

- Your article is published within days, with no editorial bias

- You can publish traditional articles, null/negative results, case reports, data notes and more

- The peer review process is transparent and collaborative

- Your article is indexed in PubMed after passing peer review

- Dedicated customer support at every stage

For pre-submission enquiries, contact research@f1000.com 